(C) The Author(s), 2021. Published by Cambridge University Press for the Arizona Board of Regents on behalf of the University of Arizona. This is an Open Access article, distributed under the terms of the Creative Commons Attribution licence (https://creativecommons.org/licenses/by/4.0/), which permits unrestricted re-use, distribution, and reproduction in any medium, provided the original work is properly cited.

\title{
WHEAT SEED (TRITICUM AESTIVUM L.) RADIOCARBON CONCENTRATION OVER THE LAST 75 YEARS
}

\author{
C Matthias Hüls ${ }^{1 *}$ (1) - Andreas Börner ${ }^{2}$ Christian Hamann ${ }^{1}$ (C) \\ ${ }^{1}$ Leibniz-Laboratory for Radiometric Dating and Isotope Research, Kiel University, Germany \\ ${ }^{2}$ Leibniz Institute of Plant Genetics and Crop Plant Research (IPK), Seeland, OT Gatersleben, Germany
}

\begin{abstract}
Here we report radiocarbon measurements made on wheat seed tissue (Triticum aestivum L.; winter or spring type growth habit), from the seed archive of the IPK Gatersleben, Sachsen-Anhalt, Germany, which was harvested between 1946 and 2020. The results give an overview of 75 years of radiocarbon concentration evolution in agricultural plant products. The wheat tissue radiocarbon concentrations follow known pre- and post-bomb radiocarbon records, such as the atmospheric Jungfraujoch, Schauinsland, and NH1 datasets. Based on a Northern Hemisphere growing period from April to July, the Gatersleben seed tissue radiocarbon concentration indicates incorporation of fossil carbon of about $1 \%$ with respect to the high alpine, clean-air $\mathrm{CO}_{2}$ of the Jungfraujoch station between 1987 and 2019. We propose to use the pre- and post-bomb radiocarbon record of Gatersleben wheat as a reference in forensic investigations, such as the age estimation of paper by analyzing starch used in paper manufacture. Additionally, an advantage of the record reported here lies in its extensibility by adding new analyses from future harvests.
\end{abstract}

KEYWORDS: bomb-curve radiocarbon, wheat seed.

\section{INTRODUCTION}

The unstable isotope of the element carbon $\left({ }^{14} \mathrm{C}\right)$ is formed in the upper atmosphere by nucleus reaction between energetic neutrons and the element nitrogen, due to cosmic particle radiation.

${ }^{14} \mathrm{CO}_{2}$ is transported within the atmosphere and distributed in natural sinks such as the biosphere and dissolved in the ocean. Any living organism takes up ${ }^{14} \mathrm{C}$ and incorporates it into its tissues, but it ceases exchange with the atmosphere at death. As ${ }^{14} \mathrm{C}$ decays with a half-life of 5730 years, measuring the remaining ${ }^{14} \mathrm{C}$ concentration allows estimation of the age of objects up to 50,000 years old.

During the last 70 years, the natural ${ }^{14} \mathrm{C}$ cycle was disrupted by human activities such as atmospheric nuclear tests (which almost doubled natural atmospheric ${ }^{14} \mathrm{C}$ concentrations by 1963 ) and emissions of ${ }^{14} \mathrm{C}$-free fossil carbon (too old to contain measurable ${ }^{14} \mathrm{C}$ ) (e.g., Suess 1955; Stuiver and Quay 1980; Rakowski et al. 2013; Prăvălie 2014). Atmospheric ${ }^{14} \mathrm{C}$ concentrations are expected to return to (or fall below) the reference level of $1\left(\mathrm{~F}^{14} \mathrm{C}\right.$; Reimer et al. 2004, defined for the year 1950), mainly due to the dilution of atmospheric $\mathrm{CO}_{2}$ by the emission of ${ }^{14} \mathrm{C}$-free $\mathrm{CO}_{2}$. This level may even have been reached already (Graven 2015; see also the discussion section). The ocean, on the other hand, may have become a source of ${ }^{14} \mathrm{C}$ for atmospheric $\mathrm{CO}_{2}$ as suggested by Andrews et al. (2016) and $\mathrm{Wu}$ et al. (2021).

The large concentration differences during the last decades allows the application of radiocarbon measurements in forensic studies, such as the determination of modern carbon contribution in fuels (Reddy et al. 2008; Norton et al. 2012) or bio-plastic (Telloli et al. 2019), investigation of the paper age of art and documents (Zavattaro et al. 2007;

\footnotetext{
*Corresponding author. Email: mhuels@leibniz.uni-kiel.de
} 
Fedi et al. 2013; Huels et al. 2017), determination of animal-tissue growth age with respect to CITES (Convention on International Trade in Endangered Species of Wild Fauna and Flora, e.g., Wild et al. 2019), or the production date of whiskey (Cook et al. 2020), to name a few.

Here we complement available reference data, such as atmospheric carbon dioxide ${ }^{14} \mathrm{C}$ measurements (e.g., Levin et al 1985, 1997, 2013; Hammer and Levin 2017) or tree-ring measurements (e.g., Hua et al. 2013), with annual radiocarbon measurements on seasonally grown plant tissue (seeds of bread wheat (Triticum aestivum L.), harvested between the years 1946-2020), from the collections of the IPK Gatersleben (Leibniz-Institut für Pflanzengenetik und Kulturpflanzenforschung). An advantage over existing reference data is the possibility to compile a continuous record of plant-tissue ${ }^{14} \mathrm{C}$ data between 1946 until today, and the possibility for continued expansion in future years.

\section{MATERIAL AND METHODS}

\section{Material}

The plant material was provided by the IPK Gatersleben, which is one of the world's leading international institutions in the field of plant genetics and crop science. With a total inventory of 150,000 accessions of 3212 plant species and 776 genera, IPK holds one of the most comprehensive collections worldwide. It comprises wild and primitive forms, landraces as well as old and more recent cultivars of mainly cereals but also other crops (Börner et al. 2012; Börner and Khlestkina 2019). The institute and its agrarian land is located east of the Harz Mountains in a rural area, dominated by agriculture (Figure 1).

Wheat (Triticum aestivum L.) was grown in the experimental fields of the IPK in Gatersleben (latitude $51^{\circ} 49^{\prime} 19.74^{\prime \prime} \mathrm{N}$, longitude $11^{\circ} 17^{\prime} 11.80^{\prime \prime} \mathrm{E}, 110.5 \mathrm{~m}$.a.s.1., black soil of clayey loamy type) from 1946 onwards. Plot size was $2 \mathrm{~m}^{2}$. Standard agronomic management according to good agricultural practice was applied. It is from this long-lasting continuous regeneration activities that samples of annual harvested wheat seeds where acquired for subsequent radiocarbon measurements.

Seeds were stored in glass tubes as reference samples in the herbarium collection of the IPK. The conditions of the storage place were a temperature of $22.5^{\circ} \mathrm{C} \pm 3{ }^{\circ} \mathrm{C}$ and a relative humidity of $45-50 \%$.

Selected seed samples consist of both winter and spring growth habit. Winter wheat was sown in October and harvested in July whereas spring wheat was sown in March/April (depending on weather conditions) and harvested in August (Opperman et al 2015). Seed tissue thus will contain atmospheric carbon metabolized between April-June and May-July, respectively, for winter and spring wheat. We take the mid of May and mid of June as the current fixpoints for defining the dates of the radiocarbon content. A comparison of mean April-June and May-July radiocarbon values of the monthly NH1-dataset (Hua et al. 2013) and atmospheric Schauinsland dataset (SIL; Hammer and Levin 2017) show small differences within measurement uncertainties which do not invalidate constructing a joint time series using both winter-sown and spring-sown wheat ${ }^{14} \mathrm{C}$ measurements.

\section{Methods}

Several grains from each season between 1946 to 2020 were available, from which one single grain was selected for further analysis. To remove possible hydrophobic substances such as 


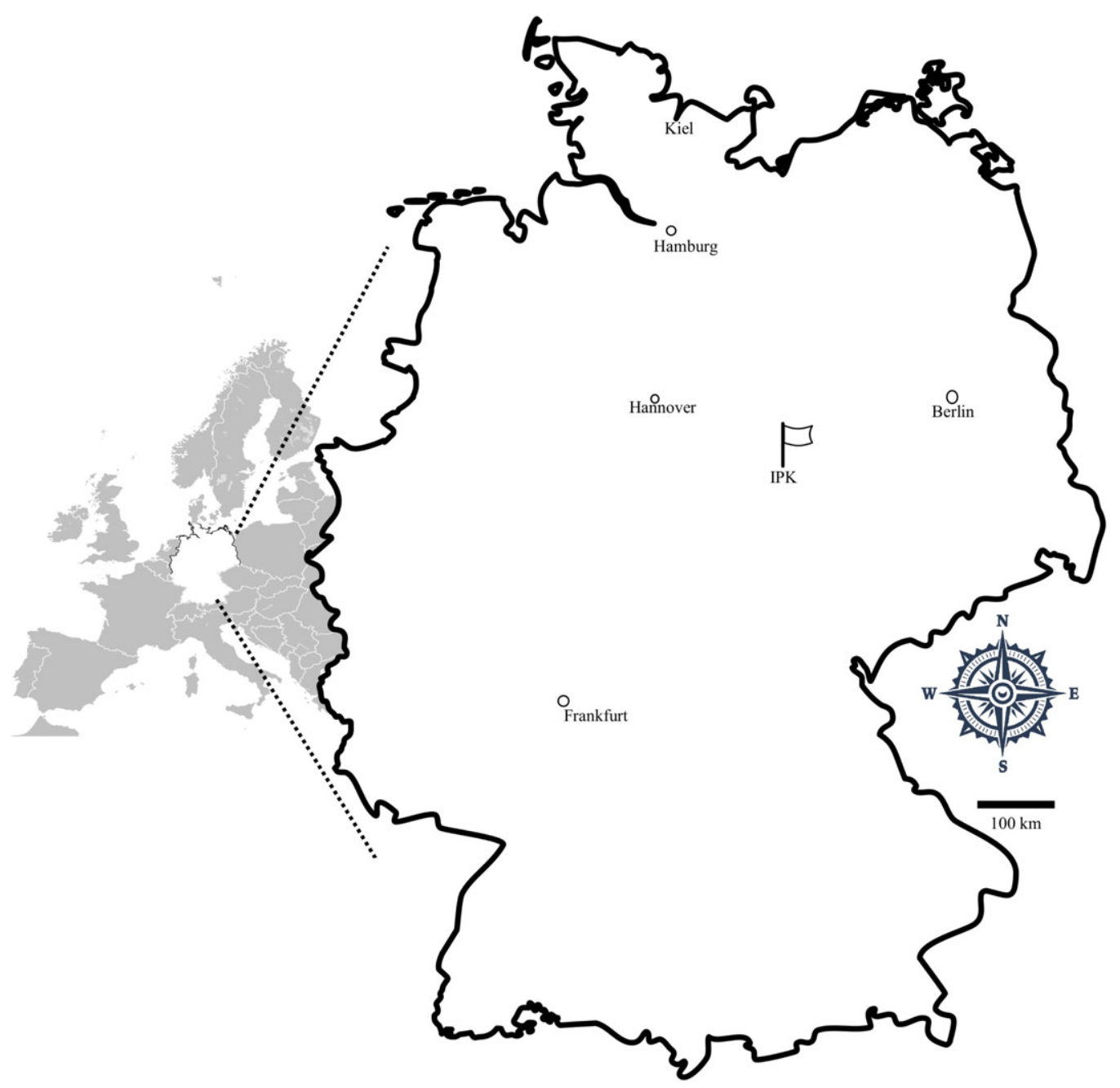

Figure 1 Location of the IPK (labeled as a flag) in Germany.

lipids from handling of seed corns, each grain was washed with acetone for $30 \mathrm{~min}$ in an ultrasonic bath, decanted, and dried subsequently at $60^{\circ} \mathrm{C}$ in an oven over night. Afterwards, the sample material was frozen in liquid nitrogen and powdered, i.e., homogenized, using pestle and mortar. From the powdered material, between 6-7 mg was flame-sealed together with $\mathrm{CuO}$ and silver in quartz-ampoules under vacuum, and finally combusted at $900^{\circ} \mathrm{C}$. Resulting $\mathrm{CO}_{2}$ was cryogenically purified and graphitized with catalytic $\mathrm{Fe}$ and $\mathrm{H}_{2}$ at $600^{\circ} \mathrm{C}$.

Radiocarbon measurements were conducted at the Leibniz-Labor with a $H V E 3 M V$ Tandetron 4130 accelerator mass spectrometer (AMS). The ${ }^{14} \mathrm{C} /{ }^{12} \mathrm{C}$ and ${ }^{13} \mathrm{C} /{ }^{12} \mathrm{C}$ isotope ratios were simultaneously measured by AMS and compared to the SRM4990C measurement standards (Oxalic Acid II). The resulting ${ }^{14} \mathrm{C}$-content is normalized to the $\delta^{13} \mathrm{C}$ concentration of $-25 \%$ for isotope fractionation correction (Stuiver and Polach 1977). 
Blank correction was performed using the modeled ${ }^{14} \mathrm{C}$ distribution vs. sample size of Alfa graphite, which is also measured regularly in each wheel of sample cathodes (Nadeau et al 1998; Nadeau and Grootes 2013). Measured radiocarbon concentration is given in $\mathrm{F}^{14} \mathrm{C}$ and $\Delta^{14} \mathrm{C}$ by correcting for the decay of the measurement standard and samples (Stenström et al. 2011; Stuiver and Polach 1977) $\left(\Delta^{14} C=\left(\left(F^{14} C * e^{\lambda(1950-x)}\right)-1\right) * 1000 ; \lambda=1 / 8267\right.$, $\mathrm{x}=\mathrm{year}$ of seed growth). Our reported uncertainty of ${ }^{14} \mathrm{C}$ results takes into account the uncertainty of the measured ${ }^{14} \mathrm{C} /{ }^{12} \mathrm{C}$ ratios of sample and measurement standard, the uncertainty of the fractionation correction and the uncertainty of the applied blank correction.

For each season or year, at least two subsamples of prepared single-grain material was measured in different batches. Variance-weighted means were calculated using

$$
\bar{x}=\frac{\sum_{i=1}^{n} \frac{x_{i}}{\sigma_{i}^{2}}}{\sum_{i=1}^{n} \frac{1}{\sigma_{i}^{2}}} \text { and } \sigma_{\bar{x}}^{2}=\frac{1}{\sum_{i=1}^{n} \frac{1}{\sigma_{i}^{2}}}
$$

with $\bar{x}$ weighted mean $\mathrm{F}^{14} \mathrm{C}$ or $\Delta^{14} \mathrm{C}$, and $\sigma_{x}$ the error of the weighted mean (Ward and Wilson 1978). When individual measurements of one sample were judged to be significantly different from each other (i.e., differences are larger than $2 \sigma$ ), an additional measurement was performed, to either improve the agreement of all individual measurements or identify a possible outlier.

\section{RESULTS}

The result of the radiocarbon measurements of the wheat samples is visualized in Figure 2 (see also Table S1 of the Supplementary Materials).

Between 1946 and 1955, wheat tissue- ${ }^{14} \mathrm{C}$ concentration stayed below the modern standard concentration of $\Delta^{14} \mathrm{C} \geq 0 \%$ (between $-28 \%$ and $-48 \%$ ) and increased subsequently towards a first maxima in $1959(285 \%$ ) as a result of the increasing number (and energy) of atmospheric nuclear tests (see Figure S1, UNSCEAR 2000; Bergkvist and Ferm 2000; Prăvălie 2014). A pause in atmospheric nuclear test activity in 1959 and only 3 tests with low energy yield in 1960 resulted a first reduction in atmospheric radiocarbon concentration by about 57\% and 67\% (1960 and 1961, respectively, see Figure S1). Nuclear test activity resumed in the second half of 1961 , causing increased atmospheric ${ }^{14} \mathrm{C}$ activity, as seen in the 1962 spring/early summer biomass ${ }^{14} \mathrm{C}$ concentration. Evolution and ${ }^{14} \mathrm{C}$ concentrations in seeds compare reasonably well to the Trondheim pine tree-ring tissues of the same period (Svarva et al. 2019: see also Figure S1).

Maximum nuclear test activity (and energy) was reached in late 1962, resulting in an increase in ${ }^{14} \mathrm{C}$ formation as seen in wheat biomass from summer 1963 (855\%o, see also Figure S1 and Table S1). Maximum atmospheric ${ }^{14} \mathrm{C}$ concentration occurred in late summer 1963 (980\%) as seen in the Northern Hemisphere 1 compilation (Hua et al. 2013), although no nuclear test activity was recorded in 1963 (UNSCEAR 2000). An agreement by signing the Limited Test Ban Treaty (LTBT or partial test ban treaty) on August 5, 1963, put an end to aboveground nuclear test activity, except minor amounts of tests conducted by China and France (e.g., Bergkvist and Ferm 2000). Maximum wheat tissue ${ }^{14} \mathrm{C}$ concentration is measured in summer 1964 sample (908\%; Figure 2, Figure S1). 

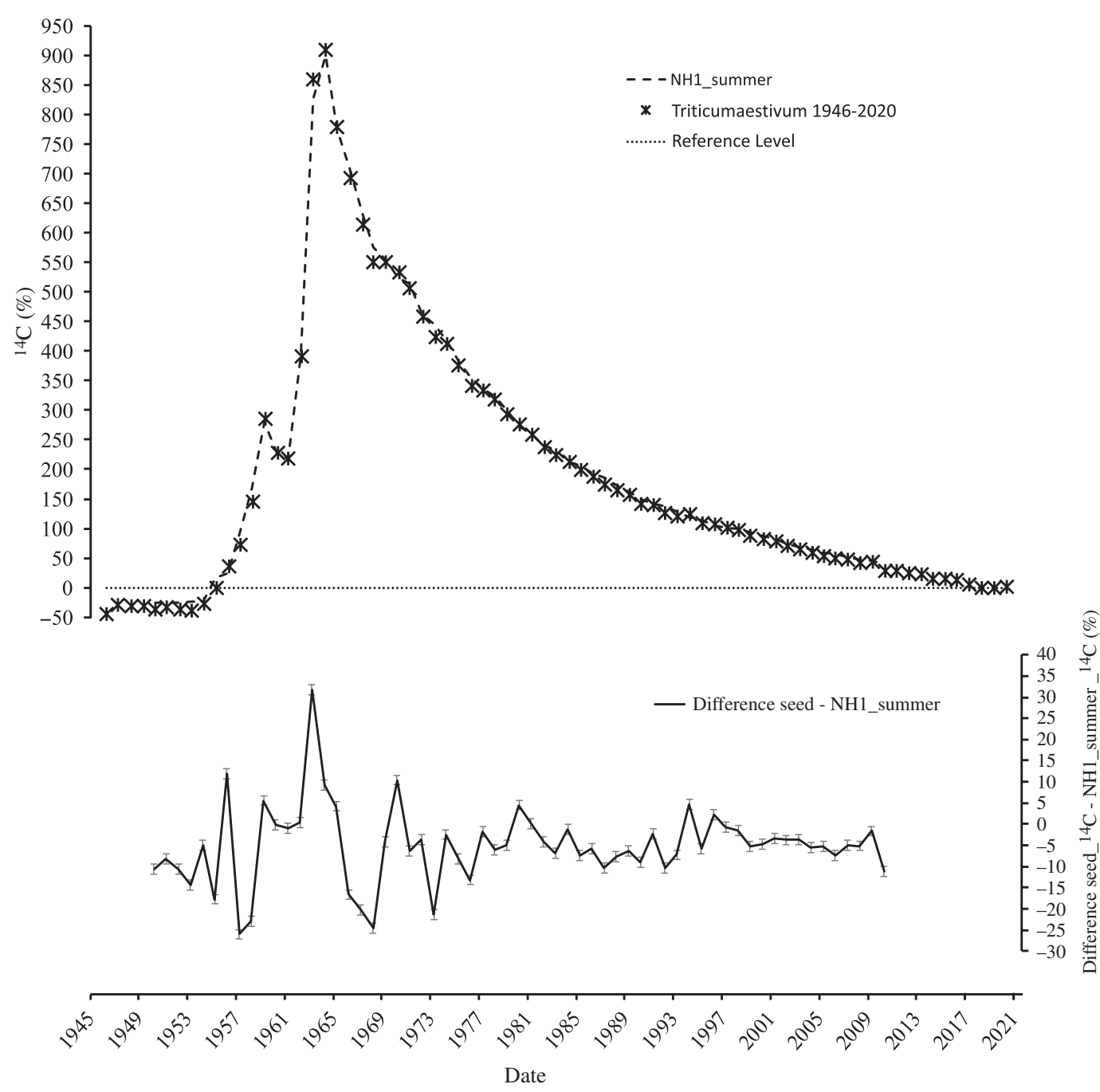

Figure 2 Radiocarbon concentration in Gatersleben-wheat tissue, grown between 1946 and 2020. Dashed line corresponds to the summer (May-August) ${ }^{14} \mathrm{C}$ of the $\mathrm{NH} 1$ compilation (Hua et al. 2013). Lower panel gives the ${ }^{14} \mathrm{C}$ differences between Gatersleben wheat and summer NH1. Error bars shown are calculated based on propagated errors from Gatersleben and NH1 datasets.

Since the LTBT, excess atmospheric ${ }^{14} \mathrm{C}$ concentration decreased as ${ }^{14} \mathrm{CO}_{2}$ was sequestered in the natural sinks such as the ocean and the biosphere. Recorded wheat-tissue ${ }^{14} \mathrm{C}$ decreased rapidly by about 90\%o/yr from the maximum concentration until 1968 (550\%o; see Figure 2), followed by a plateau with comparable concentrations in 1969 and 1970. Between 1970 and 1977, radiocarbon concentration decreased with a lower mean annual rate of about $-25 \%$ oyr. Between 1977 and 2009, annual reduction in wheat-tissue radiocarbon seem to follow an exponential function with a "time-constant" of $\mathrm{T}_{1 / 2} \approx 11 \mathrm{yr}$.

During the early and maximum phase of the bomb-pulse, seed ${ }^{14} \mathrm{C}$ and summer $\mathrm{NH} 1$ show considerably larger variability in differences, varying from $\Delta \Delta$ (seed_ ${ }^{14} \mathrm{C}$ NH1_summer_14C):-26\%o and $-25 \%$ (1957 and 1968, respectively) to $\Delta \Delta: 32 \%$ and $10 \%$ o 

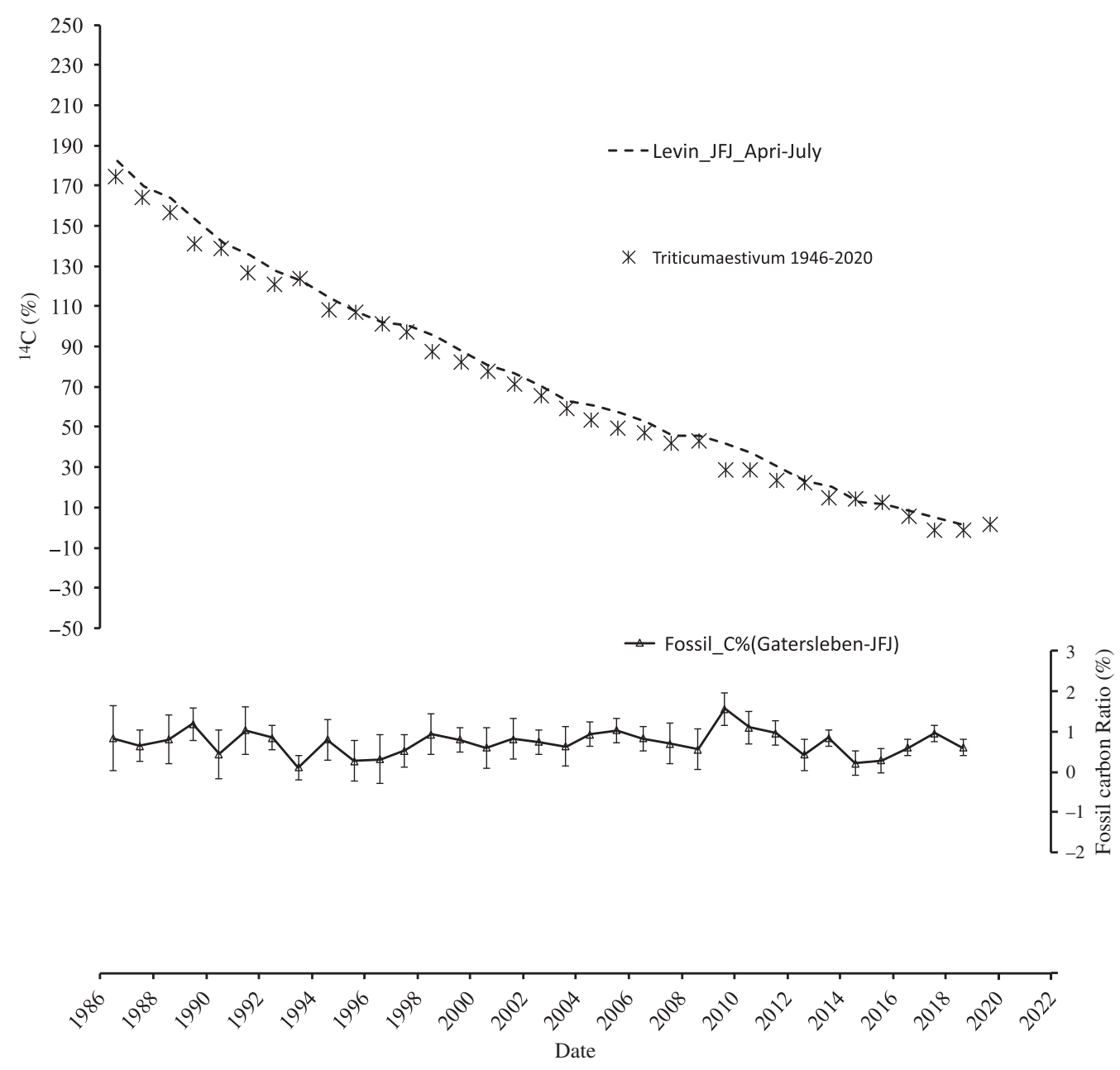

Figure 3 Wheat tissue ${ }^{14} \mathrm{C}$ (asterisks) between 1986 and 2020. Dashed line represents the atmospheric Jungfraujoch ${ }^{14} \mathrm{C}$ concentration. Black triangles and line in the lower panel give $\%$ fossil carbon in seed tissue with respect to calculated mean April-July JFJ ${ }^{14} \mathrm{C}$ (Levin and Kromer 2004; data from Hammer and Levin 2017 and Emmenegger et al. 2020). Error bars shown are calculated based on propagated errors from Gatersleben and JFJ measurements.

(1963 and 1970, respectively). The larger differences between the NH1 compilation and the seed tissue may indicate ${ }^{14} \mathrm{C}$ differences in the atmosphere, i.e. an inhomogeneous isotopic distribution within the Northern Hemisphere air parcels as was recently described for tropical South America (Ancapichún et al. 2021).

From about 1980 onwards, wheat seed ${ }^{14} \mathrm{C}$ concentrations lie closer to summer $\mathrm{NH} 1$ concentrations, but mostly with negative $\Delta \Delta$ values (differences vary from around $-10 \%$ o to $5 \%$, see Figure 2), indicating on average a generally higher fossil carbon concentration within the wheat tissue than in the NH1 dataset. 
In 2010, measured wheat ${ }^{14} \mathrm{C}$ concentration may indicate a larger fossil $\mathrm{CO}_{2}$ contribution, as seen in a considerable drop in $\Delta^{14} \mathrm{C}$ of about $14.5 \%$ (see Table $\mathrm{S} 1$ and Figure 3), compared to the previous year. Between 2016 and 2018 , wheat-tissue ${ }^{14} \mathrm{C}$ concentrations decreased faster than between 2014 and 2016 (see Figure 2 and Figure 3), followed by comparably stable ${ }^{14} \mathrm{C}$ concentrations slightly below the reference standard in 2018 and $2019(-1.4 \%$ and $-1.1 \%$, resp.). Recent 2020 wheat tissue gave again a slightly enriched ${ }^{14} \mathrm{C}$ concentration of $1.3 \%$ (see Table S1).

\section{DISCUSSION}

Overall, radiocarbon concentrations in plant tissue mirror atmospheric radiocarbon concentrations, which result from a complex interplay between radiocarbon production, partitioning into the biosphere and hydrosphere, and dilution with human-made or natural fossil, ${ }^{14} \mathrm{C}$-free carbon emission. Short-term, inter-annual, seasonal changes in fossil-fuel carbon emission as seen in atmospheric radiocarbon records such as Jungfraujoch (JFJ), Schauinsland (SIL), and Vermunt (VER) (Levin and Kromer 2004; Levin et al. 2008; Hammer and Levin 2017; Emmenegger et al. 2020), could be caused by cold season heating and energy production. Other contributions to the evolution of atmospheric ${ }^{14} \mathrm{C}$ could be changes in air-sea exchange, for example, variability in ocean upwelling (e.g., Graven et al. 2012), releasing old, ${ }^{14} \mathrm{C}$ depleted $\mathrm{CO}_{2}$ into the atmosphere. Furthermore, since the early 2000s, the North and South Pacific surface ocean have become a source of ${ }^{14} \mathrm{C}$, as indicated by ${ }^{14} \mathrm{C}$ measurements of annually precipitated carbonate of sub-surface living corals of Porites sp. (Andrews et al. 2016; Wu et al. 2021), influencing the overlying northern and southern hemispheric airmasses. To what extent the North Atlantic also became a source of enriched ${ }^{14} \mathrm{C}$ would need actualized studies such as those from Scourse et al. (2012).

Using the JFJ radiocarbon record (and calculated April-July mean values) as a reference for a clean-air site (Levin and Kromer 2004), less influenced by anthropogenic fossil fuel emissions, we estimated the fossil carbon contribution within the wheat tissue by

$$
\text { Fossil_C }(\%)=\left(1-\frac{F^{14} C_{\text {seed }}}{F^{14} C_{J F J}}\right) * 100
$$

(Quarta et al. 2007; Varga et al. 2019). Between 1987-2016, fossil C contribution in the wheat tissue is mostly lower than $1 \%$, slightly above $1 \%$ in 1990 and 1992, and with stronger excursions in 2010 and 2011 by $1-1.5 \%$ fossil C (Fossil_C $(\%)_{\text {mean }}: 0.7 \pm 0.3$; see Figure 3).

The visible pause in the ${ }^{14} \mathrm{C}$ decrease rate in ${ }^{14} \mathrm{C}$ of wheat tissue in 2009 is also observable in the April-July JFJ ${ }^{14} \mathrm{C}$ record. The pause in the ${ }^{14} \mathrm{C}$ decrease rate in wheat tissue ${ }^{14} \mathrm{C}$ in $2008-2009$, and also 2019-2020, coincide with the sunspot minima of the ending 23rd and 24th solar cycles, respectively (McIntosh et al. 2020), resulting in a larger ${ }^{14} \mathrm{C}$ production due to less solar particle shielding against cosmic particles (Stuiver 1961; Stuiver and Braziunas 1993). In addition, fossil carbon emission also dropped significantly between 2008 and 2009 (Eurostat 2020), largely caused by the Global Financial Crisis in 2008.

The comparably larger radiocarbon decrease in seed tissue in 2010 can also be observed in the atmospheric Schauinsland record, but with a much smaller magnitude, and it has no counterpart in contemporary JFJ record. The atmospheric Schauinsland radiocarbon record is located at lower elevation in the Black Forest and is partially also influenced by industrial fossil fuel contribution from the Rhine valley (Levin and Kromer 2004). 
A reduced ${ }^{14} \mathrm{C}$ content with respect to the Jungfraujoch station is also observed in plant-tissue (maize leaves) in the northern Netherlands in $2010\left(\Delta \Delta^{14} \mathrm{C}_{\mathrm{JFJ} \text {-leaves }}\right.$ of about 6\%; Bozhinova et al. 2016) and 2011, and in 2011 samples of Hungarian acacia honey $\left(\Delta \Delta^{14} \mathrm{C}_{\mathrm{JFJ}}\right.$-honey of about $10 \%$; Varga et al. 2020). The latter study cover an almost continuous period from 1994 to 2018, showing a reasonable good agreement between honey and wheat in measured ${ }^{14} \mathrm{C}$ except a short period in 2006 and 2007 with probably elevated local fossil carbon contribution seen in honey (Varga et al. 2020). In comparison to the Gatersleben seed and also the JFJ reference site, the Hungarian honey samples give elevated ${ }^{14} \mathrm{C}$ concentrations since $2014\left(\Delta \Delta^{14} \mathrm{C}_{\mathrm{JFJ} \text {-honey }}\right.$ of about -4 to $\left.-12 \%\right)$, also visible in two Slovakian wine samples from $2015\left(\Delta \Delta^{14} \mathrm{C}_{\mathrm{JFJ} \text {-wine }}\right.$ of about $-15 \%$; Povinec et al. 2020; see also Figure S2).

The Gatersleben wheat-tissue ${ }^{14} \mathrm{C}$ record is apparently influenced by fossil carbon at the order of magnitudes up to $1.6 \%$. Nevertheless, we think this record as well as other plant-based ${ }^{14} \mathrm{C}$ records covering the bomb-spike, could be useful in forensic investigations such as the assessment of paper ages (Huels et al. 2017; Pigorsch et al. 2020) or the estimation of renewable fuels e.g., products such as potato and corn (giving starch, used as a binder within and on the surface of paper), or rapeseed for biofuel production, are grown in agricultural environments, and their ${ }^{14} \mathrm{C}$ content is probably more comparable to the Gatersleben seed record and not to the more remotely located and less fossil-carbon influenced records such as the atmospheric records like Jungfraujoch or Schauinsland.

\section{CONCLUSION}

On tissue of seasonal cultivated and archived wheat seeds (Triticum aestivum L.) from the IPK Gatersleben, radiocarbon measurements have been conducted, allowing an overview of the temporal evolution of the plant tissue radiocarbon content during the growth season between 1946 and 2020. Samples consists each of winter or spring type with growth periods between April-July and May-August, respectively.

The course of the resulting radiocarbon concentrations follows published datasets such as the Northern Hemisphere (NH 1) record (e.g., Hua et al. 2013) with a sharp increase in atmospheric radiocarbon between 1955 and 1964 as a consequence of atmospheric nuclear testing activities until 1963, followed by a steep reduction in atmospheric radiocarbon concentration due to partitioning into the bio- and hydrosphere of about 90\%o/yr. until 1968 . The rate of reduction in atmospheric ${ }^{14} \mathrm{C}$ slows down significantly in following decades. For the last 10 years, the reduction in atmospheric ${ }^{14} \mathrm{C}$ concentration appeared discontinuous with sudden drops. The youngest (2018-2020) measured wheat tissue radiocarbon concentrations vary around $-1.4 \%$ (2018) and $1.3 \%$ (2020). The Gatersleben seed radiocarbon record indicate a fossil carbon contribution in the plant tissue up to $1.6 \%$ when compared to the high alpine, clean-air Jungfraujoch record. Nevertheless the Gatersleben radiocarbon record as well as other potential future other agricultural records could be suitable in forensic investigation because of their closer comparability in material and growth situation. It is planned to continue radiocarbon measurements on seeds of coming harvests.

\section{ACKNOWLEDGMENTS}

The authors would like to thank the technical staff of the Leibniz-Laboratory for their commitment in sample handling. $\mathrm{M} \mathrm{H}$ appreciated the constructive comments of two 
anonymous reviewers as well as from Associate Editor Quan Hua, helping to shape and improve the present article.

\section{SUPPLEMENTARY MATERIAL}

To view supplementary material for this article, please visit https://doi.org/10.1017/RDC. 2021.81

\section{REFERENCES}

Ancapichún S, De Pol-Holz R, Christie DA, Santos GM, Collado-Fabbri S, Garreaud R, Lambert F, Orfanoz-Cheuquelaf A, Rojas M, Southon J, Turnbull J, Creasman PP. 2021. Radiocarbon bomb-peak signal in tree-rings from the tropical Andes register low latitude atmospheric dynamics in the Southern Hemisphere. Science of the Total Environment 774:145126.

Andrews AH, Siciliano D, Potts DC, Demartini EE, Covarrubias S. 2016. Bomb radiocarbon and the hawaiian archipelago: coral, otoliths, and seawater. Radiocarbon 58(3):531-548.

Bergkvist N-O, Ferm R. 2000. Nuclear explosions 1945-1998. Stockholm.

Börner A, Khlestkina KE. 2019. Ex-situ genebanksseed treasure chambers for the future. Russian Journal of Genetics, 55, 1299-1305.

Börner A, Khlestkina EK, Chebotar S, Nagel M, Arif MAR, Neumann K, Kobiljski B, Lohwasser U, Röder MS. 2012. Molecular markers in management of ex situ PGR - a case study. Journal of Biosciences 37(5):871-877.

Bozhinova D, Palstra SWL, van der Molen MK, Krol MC, Meijer HAJ, Peters W. 2016. Three years of $\Delta^{14} \mathrm{CO}_{2}$ observations from maize leaves in the Netherlands and Western Europe. Radiocarbon 58:1-20.

Cook GT, Dunbar E, Tripney BG, Fabel D. 2020. Using carbon isotopes to fight the rise in fraudulent whisky. Radiocarbon 62(1):51-62.

Culp R, Cherkinsky A, Ravi Prasad G V. 2014. Comparison of radiocarbon techniques for the assessment of biobase content in fuels. Applied Radiation and Isotopes 93:106-109.

Emmenegger L, Leuenberger M, Steinbacher M, RI I. 2020. ICOS ATC, CAL ${ }^{14} \mathrm{C}$ release, Jungfraujoch $(10.0 \mathrm{~m})$. Retrieved from https://hdl.handle.net/ 11676/X-1XPKZ1O4DWX7wncsLQ7akY.

Eurostat. 2020. Greenhouse gas emission statisticsemission inventories. Eurostat 63(3):175-180. Retrieved from http://ec.europa.eu/eurostat/statistic sexplained/.

Fedi ME, Caforio L, Mandò PA, Petrucci F, Taccetti F. 2013. May ${ }^{14} \mathrm{C}$ be used to date contemporary art? Nuclear Instruments and Methods in Physics Research B 294:662-665.

Graven HD. 2015. Impact of fossil fuel emissions on atmospheric radiocarbon and various applications of radiocarbon over this century. Proceedings of the National Academy of Sciences 112(31): 9542-9545.

Graven HD, Guilderson TP, Keeling RF. 2012. Observations of radiocarbon in $\mathrm{CO}_{2}$ at la Jolla, California, USA 1992-2007: analysis of the long-term trend. Journal of Geophysical Research Atmospheres 117(2):1-14.

Hammer S, Levin I. 2017. Monthly mean atmospheric $\mathrm{D}^{14} \mathrm{CO} 2$ at Jungfraujoch and Schauinsland from 1986 to 2016. https://doi.org/ doi/10.11588/data/10100.

Hua Q, Barbetti M, Rakowski A Z. 2013. Atmospheric radiocarbon for the period 1950-2010. Radiocarbon 55(4):2059-2072.

Huels M, Pensold S, Pigorsch E. 2017. Radiocarbon measurements of paper: a forensic case study to determine the absolute age of paper in documents and works of art. Radiocarbon 59(5): 1553-1560.

Levin I, Hammer S, Kromer B, Meinhardt F. 2008. Radiocarbon observations in atmospheric $\mathrm{CO}_{2}$ : determining fossil fuel $\mathrm{CO}_{2}$ over Europe using Jungfraujoch observations as background. Science of the Total Environment 391(391): 211-216.

Levin I, Kromer B. 2004. The tropospheric ${ }^{14} \mathrm{CO}_{2}$ level in mid-latidudes of the northern hemisphere (1959-2003). Radiocarbon 46(3):1261-1272.

McIntosh S W, Chapman S, Leamon R J, Egeland R, Watkins N W. 2020. Overlapping magnetic activity cycles and the sunspot number: forecasting sunspot cycle 25 amplitude. Solar Physics 295(12).

Nadeau M-J, Grootes PM, Schleicher M, Hasselberg P, Rieck A, Bitterling M. 1998. Sample throughput and data quality at the LeibnizLabor AMS facility. Radiocarbon 40:239-245.

Nadeau M-J, Grootes PM. 2013. Calculation of the compounded uncertainty of C AMS measurements. Nuclear Instruments and Methods in Physics Research 294:420-425.

Norton G A, Cline, A M, Thompson G C. 2012. Use of radiocarbon analyses for determining levels of biodiesel in fuel blends-comparison with ASTM Method D7371 for FAME. Fuel 96:284-290.

Oppermann M, Weise S, Dittmann C, Knüpffer H. 2015. GBIS: the information system of the German Genebank Database bav021. https:// doi.org/10.1093/database/bav021. 
Pigorsch E, Kießler B, Hüls M, Meinl G. 2020. Altersbestimmung von Papier - Möglichkeiten für eine absolute Datierung von Dokumenten und Kunstwerken. Kriminalistik (8-9): 556-562.

Povinec PP, Kontul' I, Lee SH, Sýkora I, Kaizer J, Richtáriková M. 2020. Radiocarbon and 137Cs dating of wines. Journal of Environmental Radioactivity 217:106205.

Prăvălie R. 2014. Nuclear weapons tests and environmental consequences: a global perspective. Ambio 43(6):729-744.

Quarta G, Rizzo GA, D'Elia M, Calcagnile L. 2007. Spatial and temporal reconstruction of the dispersion of anthropogenic fossil $\mathrm{CO}_{2}$ by ${ }^{14} \mathrm{C}$ AMS measurements of plant material. Nuclear Instruments and Methods in Physics Research B 259:421-425.

Rakowski AZ, Nadeau M-J, Nakamura T, Pazdur A. 2013. Radiocarbon method in environmental monitoring of $\mathrm{CO}_{2}$ emission. Nuclear Instruments and Methods in Physics Research 294:503-507.

Reddy CM, DeMello JA, Carmichael C A, Peacock EE, Xu L, Arey J S. 2008. Determination of biodiesel blending percentages using natural abundance radiocarbon analysis: testing the accuracy of retail biodiesel blends. Environmental Science \& Technology 42(7): 2476-2482.

Reimer PJ, Brown TA, Reimer RW. 2004. Discussion: reporting and calibration of post-bomb ${ }^{14} \mathrm{C}$ data. Radiocarbon 46(3): 1299-1304.

Scourse JD, Wanamaker AD, Weidman C, Heinemeier J, Reimer PJ, Butler PG, Witbaard R, Richardson CA. 2012. The marine radiocarbon bomb pulse across the temperate North Atlantic: a compilation of $\Delta^{14} \mathrm{C}$ time histories from Arctica Islandica growth increments. Radiocarbon 54(2):165-186.

Stenström KE, Skog G, Georgiadou E, Genberg J, Johansson A. 2011. A guide to radiocarbon units and calculations. Vol. 6. Lund, Sweden: Lund University Department of Physics.

Stuiver M. 1961. Variations in radiocarbon concentration and sunspot activity. Journal of Geophysical Research 66(1):273-276.

Stuiver M, Braziunas TF. 1993. Sun, ocean, climate and atmospheric ${ }^{14} \mathrm{CO}_{2}$ : an evaluation of causal and spectral relationships. The Holocene 3(4): 289-305.

Stuiver M, Polach HA 1977. Reporting of ${ }^{14} \mathrm{C}$ data: a discussion. Radiocarbon 19(3):355-363.

Stuiver M, Quay PD. 1980. Changes in atmospheric carbon-14 attributed to a variable Sun. Science 207(4426):11-19.

Suess HE. 1955. Radiocarbon concentration in modern wood. Science 122(3166):415-417.

Svarva H, Grootes P, Seiler M, Stene S, Thun T, Vaernes E, Nadeau M-J. 2019. The 1953-1965 rise in atmospheric bomb ${ }^{14} \mathrm{C}$ in central Norway. Radiocarbon 61(6):1765-1774.

Telloli C, Rizzo A, Canducci C, Bartolomei P. 2019. Determination of bio content in polymers used in the packaging of food products. Radiocarbon 61(6):1973-1981.

UNSCEAR_AnnexC. 2000. Report to the General Assembly; Annex C: exposures to the public from man-made sources of radiation. Vienna: United Nations Scientific Commuttee on the Effects of Atomic Radiation (UNSCEAR).

Varga T, Barnucz P, Major I, Lisztes-Szabó Z, Jull AJT, László E, László E, Pénzes J, Molnár M. 2019. Fossil carbon load in urban vegetation for Debrecen, Hungary. Radiocarbon 61(5): 1199-1210.

Varga T, Sajtos Z, Gajdos Z, Jull AJT, Molnár M, Baranyai E. 2020. Honey as an indicator of long-term environmental changes: MP-AES analysis coupled with ${ }^{14} \mathrm{C}$-based age determination of Hungarian honey samples. Science of the Total Environment 736:139686.

Ward GK, Wilson SR. 1978. Procedures for comparing and combining radiocarbon age determinations: a critique. Archaeometry 20(1): 19-31.

Wild EM, Kutschera W, Meran A, Steier P. 2019. ${ }^{14} \mathrm{C}$ bomb peak analysis of African elephant tusks and its relation to cites. Radiocarbon 61(5): 1619-1624.

Wu Y, Fallon SJ, Cantin NE, Lough JM. 2021. Surface ocean radiocarbon from a porites coral record in the Great Barrier Reef: 1945-2017. Radiocarbon 63(4):1193-1203.

Zavattaro D, Quarta G, D'Elia M, Calcagnile L. 2007. Recent documents dating: an approach using radiocarbon techniques. Forensic Science International 167(2-3):160-162. 